\title{
Linguo-cognitive Structuring of Description and Narration in the Ekphrastic Space of John Berger's Essay on Diego Velázquez
}

\author{
T. V. Lunyova
}

Kyiv National Linguistic University, Kyiv, Ukraine
Corresponding author. E-mail: lunyovat@gmail.com

Paper received 03.02.20; Accepted for publication 19.02.20.

\section{https://doi.org/10.31174/SEND-Ph2020-218VIII66-08}

\begin{abstract}
The article examines the linguo-cognitive means employed to structure the descriptive and narrative ekprastic elements in Jonh Berger's essay on Diego Velázquez's paintings. A close scrutiny is given to such essay contexts where Velázquez's "Aesop", "The Fable of Arachne" and portraits of the buffoons are discussed. With the linguopoetic methodology of analysis employed in the study, the ekphrastic space has been treated as a liguo-cognitive phenomenon. The analysis has revealed that the ekphrastic space in the essay possesses two characteristic features: it allows for the intimate intertwining of the descriptive and narrative elements as well as provides room for several alternative possibilities for presenting both description and narration connected with the picture.
\end{abstract}

Keywords: ekphrasis, essay, visual arts, description, narration, story, linguo-cognitive structuring, linguistic means.

Introduction. While the term ekphrasis is frequently translated from Greek as "description" [4], it is quite often discussed with the application of the term narration. On the one hand, the shield of Achilles in Homer's Iliad as the earliest known example of ekphrasis $[9 ; 8 ; 4]$ is typically treated as a description. This description is characterised as providing elaborate details [4], for example such objects as "constellations, pastures, dancing, and great cities" [4]. On the other hand, it is noted that Homer's passage about Achilles' shield shows not only the appearance of this object but also its production: "The distinctive feature of Homer's description is that it is not really a descriptive "arresting of movement" at all, but a continuation of the narrative" [8]. Indeed, Homer tells about Achilles' shield in the form of a narrative of Hephaistos forging it [1, p. 17]. If the necessary precaution is taken to keep in mind the difference between ekphrasis as an ancient Greek rhetorical exercise and a modern specific text or a textual fragment with the verbal representation of a visual object, the discussion of Achilles' shield in Homer's epic poem may be treated as emblematic of the duality of description and narration in an ekphrasis. The current study aspires to make a contribution to the discussion of ekphrastic description and narration.

Literature review. The descriptive and narrative aspects of ekphrasis find both specified accounts of the instances of the verbal representation of visual objects and generalizing theorization on the nature of such renderings. In his study on the ekphrasis in Cervantes' pastoral novel La Galatea, Frederick A. De Armas finds out that the first appearance of Galatea in the novel "replicates Raphael's fresco of The Triumph of Galatea" [1, p. 17]. The researcher highlights that "instead of describing the painting, Cervantes sets it in motion as Galatea walks through the scene, attempting to avoid the lovesick shepherds" [1, p. 17]. Thus, concludes the scholar, "rather than a static description of a work of art, we have a narrative filled with movement" [1, p. 17].

Analysing the nature of ekphrasis through the prism of Plato's philosophical conception, Robert Hodel observes that ekprasis can grip the reader with its dynamic content as it describes battles or races [6, p. 24]. This dynamics is inevitably connected with the description of the picture and an enumeration of objects is replaced with the detailed description of one of them [6, p. 24]. Such contemplations reveal the interconnectedness of the descriptive (providing objects descriptions and enumerations) and narrative (accounting for the battles or races) aspects of ekphrasis.

Dmitriy Tokarev comes to a similar understanding of the descriptive - narrative duality of ekphrasis [10, p. 65] even though he placed his research in another theoretical framework which is Heinrich Wölfflin's discrimination between the linear and painterly precepts in art history [10, p. 63]. Tokarev pairs the linear precept with the ekphrastic description and the painterly precept with the ekphrastic narration $[10$, p. 65]. The scholar takes an inner progression and transformation of one thing into another as indicative of narration, while a move from one thing to another without such an inner progression or development he attributes to description [10, p. 66].

While summing up the results of Lausanne Symposium "Ekphrasis in Russian Literature", Leonid Geller underscores the paradoxical nature of ekphrasis because the categories which are considered to be the opposites exhibit the penetrability of their boundaries, such categories mix with each other and coexist in ekphrasis [5, p. 46]. Narration and demonstration are listed among such interpenetrating categories of ekphrasis [5, p. 46].

This overview of the scholarship on the descriptive - narrative duality of ekphrasis opens up a promising avenue for a further research that might discover the peculiarities of the description and narration in ekphrastic texts belonging to different genres. The impetus for writing this paper came from the lack of research on the linguo-cognitive means of structuring descriptive and narrative aspects of ekphrasis in essays on the visual arts.

The aim of the paper is to reveal the peculiarities of the linguo-cognitive structuring of the descriptive and narrative ekprastic elements in Jonh Berger's essay on Diego Velázquez's paintings.

Material and methods. The material of this study consists of the verbal descriptive and narrative contexts in Berger's essay [2, p. 112-136]. The methods of analysis are grounded in the linguopoetic approach to ekphrasis [12; 7 , p. 285-290]. Thus ekphrasis is treated as a liguo-cognitive phenomenon and ekphrastic space is designated as a complex verbalized cognitive phenomenon which is connected with the generation of new meanings as a result of the interaction between the visual and the verbal. While analysing the constituents of the ekphrastic space, the term conceptual cluster is used in this paper. Though used tentatively, this term is designed to mean a complex conceptual structure 
which combines two or more concepts. The account of the cognitive structure of a narration which, following Mark Turner, is understood in the paper as a cognitive phenomenon [11, p. 4-5], is given in Turner's terms of the actors, objects and events of a story [11, p. 9-10].

Results and discussion. Berger's essay entitled 'Diego Velázquez" [2] submits to scrutiny Velázquez's paintings "Aesop", "The Fable of Arachne" as well as portraits of the buffoons placing them in the context of Spanish painting tradition. The ekphrastic space of the essay is evoked right in the first paragraph: "The image impressed me when I set eyes upon it for the first time. It was as if it was already familiar, as if, as a child, I had already seen the same man framed in a doorway. The picture was painted by Velázquez around 1640. It is an imaginary, half-life-size portrait of Aesop." [2, p. 112]. A whole set of linguistic means is employed in the quoted passage for the purpose of creating the ekphrastic space: the propositional structure the picture was painted, the lexeme portrait and the personal name of the famous painter Velázquez. Besides, in the context of the textual proximity and sematic relation to the lexemes picture and portrait, the seme "picture" of the lexeme image is actualised. This seme is registered in the Cambridge Dictionary in one of the meanings of the lexeme image: "any picture, especially one formed by a mirror or a lens" [3]. At the same time, the semantic component "especially one formed by a mirror or a lens" is not actualised in this context as it has no semantic support from any other lexical means in the paragraph which focuses entirely on the picture/ portrait/ image as painted by an artist.

Having been created, the ekphrastic space of the essay gives room for the verbal representation of the picture provided in the second paragraph: "He stands there, keeping a rendezvous. With whom? A bench of judges? A gang of bandits? A dying woman? Travellers asking for another story?" [2, p. 112]. In this passage the syntactic structure He stands there, keeping a rendezvous refers to Aesop as depicted in Velázquez's painting. The combination of the Present Simple tense of the verb to stand and Participle I of the verb to keep used as an adverbial modifier simultaneously evokes two concepts of time: the concept of the ETERNAL TIME and the concept of a PASSING MOMENT. Thus both the descriptive and the narrative aspects of ekhprasis are activated in the essay.

These ekphrastic dimensions are filled in the essay with the specific components in a non-trivial way. Rather than provide a definitive description or a clear story, Berger opens up a range of possibilities with his array of questions With whom? A bench of judges? A gang of bandits? A dying woman? Travellers asking for another story? This questioning continues in the next, the third paragraph of the essay, with "Where are we?" [2, p. 112]. At this point an indefinitely wide range of possibilities is narrowed down to just two alternative answers to the posed question: "Some say that the wooden bucket and the Chamois leather indicate $\underline{a}$ tannery, and these same commentators remember Aesop's fable about the man who learned gradually to ignore the stench of tanning hides. I'm not entirely convinced. Perhaps we are at an inn, amongst travellers on the road. His boots are as used as nags with sway backs. Yet at this moment he is surprisingly dust-free and clean. He has washed and douched his hair, which is still a little damp. ” [2, p. 112]. In the given quote the lexeme tannery objectifies the concept
TANNERY while the lexeme inn actualises the concept INN. These concepts create two "local ekphrastic spaces" or "ekphrastic locations" within the ekphrastic space evoked in the essay. Both these local ekphrastic spaces contain description and narration ekphrastic elements combined into a tricky interplay.

The local ekphrastic space TANNERY includes the following descriptive elements: the conceptual cluster WOODEN BUCKET (represented with the attributive word combination wooden bucket) and the conceptual cluster CHAMOIS LEATHER (evoked with the attributive word combination the Chamois leather). These both conceptual clusters fall under the category of the "objects in the space". The narrative element enters the local ekphrastic space TANNERY with the reference to an Aesop's fable (commentators remember Aesop's fable) and a brief account of the plot of the story which is semantically connected with the descriptive ekhprastic passage as it is linked with the concept TANNERY as well: about the man who learned gradually to ignore the stench of tanning hides. The quoted above syntactic structure presents the actor of the story (man), the objects of the story (the stench of tanning hides) and the events of the story (learned gradually to ignore).

The local ekphrastic space INN contains the following descriptive elements: the concepts TRAVELLER (objectified with the lexeme travellers), the concept ROAD (represented with the lexeme road), the concept CLEAN (clean), the conceptual cluster USED BOOTS (boots are as used) and the conceptual cluster AN OLD HORSE IN POOR CONDITION (as nags with sway backs), the conceptual cluster DUST FREE (dust-free). The narrative element enters the local ekphrastic space INN in the form of the sentence He has washed and douched his hair, which is still a little damp that objectifies the actor of the story (he referring in the context to Aesop), the object of the story (his hair) and the events of the story (washed and douched). It should also be noted that the attributive syntactic structure his hair, which is still a little damp contributes not only to filling in the narrative dimension of the local ekphrastic space INN but also to its descriptive dimension with its characterization of Aesop's hair.

The two local ekphrastic spaces discussed above are represented through the tentative modus of weaker/ stronger possibilities: Berger claims "I'm not entirely convinced" while discussing one interpretation of Velázquez's "Aesop"; however, he introduces his own interpretation with the not so certain perhaps.

So far the close analysis of the ekphrastic space in Berger's essay on Velázquez's paintings has revealed the two characteristic features of this space: the intimate intertwining of the descriptive and narrative ekphrastic elements as linguo-cognitive entities and the tentative modus of several (almost) equally likely possibilities in presenting both description and narration. The series of alternatives for the picture "Aesop" by Velázquez is extended with yet one more possibility at the end of the essay. Having discussed other canvases by Velázquez and different Spanish artists, Berger returns to "Aesop": "One might have expected it from Velázquez! I think he's in front of a mirror. I think the entire painting is a reflection. Aesop is looking at himself. Sardonically, for his imagination is already elsewhere. In a minute he will turn and join the public. In a minute the mirror will reflect an empty room, through whose wall the sound of occasional 
laughter will be heard." [2, p. 133]. In the given quote the syntactic structures One might have expected it from Velázquez! and I think introduce the possibility of another alternative. The Present Simple verbal form (he's) evokes the concept of the ETERNAL TIME and thus paves the way for the descriptive elements. The Future Simple Forms (will turn and join, will reflect, will be heard) actualise the concept of a PASSING MOMENT as well as raise expectation of the narrative elements. The discussed passage creates the third local ekphrastic space IN FRONT OF A MIRROR (I think he's in front of a mirror). While offering the third interpretation of Velázquez's "Aesop", this local ekphrastic space does not destroy the other two local ekphrastic spaces, namely TANNERY and INN, for both possibilities may be probable: one might stand in front of a mirror in a tannery or in an inn.

The same principles of the intimate intertwining of the descriptive and narrative ekphrastic elements and providing the tentative modus for the picture discussion are applied to the local ekphrastic spaces that host the verbal account of the pictures "The Fable of Arachne" and portraits of the buffoons.

The ekprastic space for representing the picture "The Fable of Arachne" is evoked in the essay with the help of the possessive word combination Velázquez's canvas and the names of the picture: “Consider Velázquez's canvas which was once called The Tapestry Makers and now is entitled The Fable of Arachne. " [2, p. 131]. The ekphrastic representation of the pictures "The Fable of Arachne" begins with setting the tentative modus of the two likely possibilities: "Consider Velázquez's canvas which was once called The Tapestry Makers and now is entitled The Fable of Arachne. It was always thought to be one of the painter's last works, but recently certain art historians (for reasons which to me are not convincing) have dated it ten years earlier. "'. This quote notes two possible datings of the same picture through evoking the conceptual clusters PAINTER'S LAST WORK (objectified with the attributive word combination painter's last works) and PAINTER'S EARLIER WORK (actualised with the syntactic structure art historians have dated it ten years earlier). The narrative ekphrastic elements are given in the form of retelling a story by Ovid: "The story of Arachne, as related by Ovid, tells how a Lydian girl (we see her on the right, winding a skein of wool into a ball) made such famous and beautiful tapestries that she challenged the goddess of the arts and crafts, Pallas, to a contest. Each had to weave six tapestries. Pallas inevitably won and, as a punishment, turned Arachne into a spider." [2, p. 131]. In the selected passage the proper name Arachne, the word combination a Lydian girl, the lexeme a spider as well as the descriptive reference the goddess of the arts and crafts and another proper name Pallas represent the two actors of the story. The objects of the story are represented with the following linguistic means: a word combination a skein of wool, the lexeme $a$ ball, the attributive word combination $f a$ mous and beautiful tapestries, as well as the quantifying word combination six tapestries. The events in the story are verbalized with the help of different verbal forms: Participle I winding, the Past Simple forms made, challenged, had to weave, won, turned into as well as the noun a contest. Right after the narrative ekphrastic elements, the descriptive ekphrastic elements are provided: "In the painting of Velázquez both are at work (the woman on the left at the spinning wheel is Pallas) and in the background in the lighted alcove there is a tapestry by Arachne which vaguely refers to Titian's painting The Rape of Europa” [2, p. 131]. This whole passage ensures quite rich ekphrastic description of the painting.

In order to sustain the argument developed in this paper, let us provide a brief account of the ekphrastic representation of Velázquez's pictures of the buffoons which are given in Berger's essay. The ekprastic space for representing these canvases is set by the lexemes portraits, painted and the artist's name Velázquez: "I go in the evening to find the portraits of the buffoons painted by Velázquez" [2, p.134]. This space then embraces both descriptive and narrative elements. The descriptive ekphrasis may be illustrated with the following quote from the essay: "He's one of the dwarfs, he's the one who squints. There are two portraits of him. I one he's standing, and holding at arm's length, mockingly, a painted, miniature object which commentators haven 't exactly identified - it's thought to be part of some kind of grinding machine ..." [2, p. 135]. The verbal means which represent the descriptive ekphrasis in the quote above are underlined. It is worth noting that the quote under analysis also sets the tentative modus of possible interpretations with the help of the syntactic structures object which commentators haven 't exactly identified and it's thought to be part of some kind of grinding machine. The narrative ekprasis of the portraits of buffoons is provided in the following passage: "They [the buffoons painted by Velázquez] simply find themselves - after the laughter - beyond the transient.” [2, p. 136] where the pronoun they which refers to the buffoons painted by Velázquez represents the actors of the story and the verbal structure find themselves represents the event.

It is significant that the last paragraph of the essay contains both descriptive and narrative ekphrastic elements despite being quite brief: “Juan the Pumpkin's still eyes look at the parade of life and at us through a peephole from eternity. This is the secret that a meeting in the Rambla suggested to me." [2, p. 136]. In this paragraph the concept of the ETERNAL TIME is evoked by the lexeme eternity and the Present Simple tense of the verb look while the concept of a PASSING MOMENT is actualised by the past Simple tense form of the verb suggested. Such a double verbal actualisation, as it has been argued in this paper, enables both the descriptive and the narrative ekphrastic elements to be used. In the essay, the former are represented with the first sentence and the latter are given in the second sentence. The proper name Rambla in the last sentence is semantically connected with the previous context which directly precedes the ekphrastic discussion of the Velázquez's portraits of the buffoons: 'But the dead have not departed; the 'present' in which they were painted, the present invented by their painters, is as vivid and inhabited as the lived present of the moment. Occasionally more vivid. The inhabitants of those painted moments mingle with the evening's visitors and together, the dead and the living, they transform the galleries into a Rambla." [2, p. 134]. This context is used to create and verbalize the conceptual metaphors AN ART GALLERY IS A STREET (transform the galleries into a Rambla) and LOOKING AT THE DEPICTED PEOPLE IS MEETING PEOPLE (The inhabitants of those painted moments mingle with the evening 's visitors). These metaphors are novel ones (at least they sound really fresh in the essay) and arise in the ekphrastic space of the essay as a result of 
the interaction of the description (the first two sentences in the recent quote) and narration (the last sentence in this quote) in the passage currently discussed. These two metaphors are evoked in the last sentence of the essay (This is the secret that a meeting in the Rambla suggested to me).

Conclusion. Overall, Berger's essay on Velázquez's paintings masterfully utilises the potential of ekphrasis to open itself to both description and narration. Their intermittent evocation in the essay sets a special rhythm which keeps the ideas in the essay going and enables creation of a new meaning through the structuring of a fresh conceptual metaphor. The main peculiarity of the linguo-cognitive structuring of the descriptive and narrative ekprastic elements in the essay is providing a range of possible alternative meanings for both descriptive and narrative dimensions of the ekphrastic space. This peculiarity is grounded in the nature of Velázquez's art which is full with ambiguities and corresponds to Berger's style of thinking with the author's respects for alternatives.

The subsequent research on the linguo-cognitive structuring of the descriptive and narrative ekphrastic elements in essays on the visual arts will help to illuminate the details of the interconnection between description and narration in the ekphrastic space as well as come to a reasonable generalization on the topic.

\section{REFERENCES}

1. Armas de F. A. Simple Magic: Ekphrasis from Antiquity to the Age of Cervantes//Ekphrasis in the Age of Cervantes/ed. by F. A. De Armas. Lewisburg, PA: Bucknell University Press, 2005. 241. P. 13-31.

2. Berger J. Diego Velázquez//Berger J. Portraits: John Berger on Artists/ed. By T. Overton. London, New York: Verso, 2015. P 112-136.

3. Cambridge Dictionary. Available from: https://dictionary.cambridge.org/dictionary/english/_(Accessed on 21.01.2020)

4. Corn A. Notes on Ekphrasis. Available from: https://www.poets.org/poetsorg/text/notes-ekphrasis (Accessed on 17.01.2020)

5. Geller L. Ekphrasis, or Exposure of the device. A few questions and a thesis//"Inexpressibly expressible": ekphrasis and problems of visual representation in a literary text: Collection of articles/Compilation and scientific editig D.V. Tokarev. Moscow: New literary review, 2013. Р. 44-60 (in Russian: Геллер P. Экфрасис, или Обнажение приема. Несколько вопросов и тезис//«Невыразимо выразимое»: экфрасис и проблемы репрезентации визуального в художественном тексте: Сборник статей/Составление и научная редакция Д. В. Токарева. Москва: Новое литературное обозрение, 2013. С. 44-60).

6. Hodel R. Ekphrasis and "demodalization" of an utterance//Ekphrasis in Russian Literature: Proceeding of the Lausanne Symposium/ed. by L. Geller. Moscow: The Publishing house "MIK". 2002. P. 23-30 (in Russian: Ходель Р. Экфрасис и «демодализация» высказывания//Экфрасис в русской литературе: Труды Лозанского симпозиума/под. ред. Л. Геллера. Москва: Изд-во «МИК», 2002. С. 23-30).

7. Izotova N. P. Ludic Stylistics of Contemporary English Fictional Narrative from a Linguistic Perspective: A Study of J. M. Coetzee's Novels. Thesis for a Doctoral Degree in Philology: Speciality 10.02.04. Kyiv National Linguistic University, 2018. 458 p. (In Ukrainian: Ізотова Н.П. Ігрова стилістика сучасного англомовного художнього наративу в лінгвістичному висвітленні (на матеріалі романів Дж. М. Кутзее): дис. ... д-ра філол. наук: 10.02.04. Київ, КНЛУ, 2018. 458 с.).
8. Mitchell W. J. T. Ekphrasis and the Other//Picture Theory. Chicago: The University of Chicago Pres, 1994. Available from: http://www.rc.umd.edu/editions/shelley/medusa/mitchell.html (Accessed on 1.03.2018).

9. Rosand D. Ekphrasis and the Generation of Images//Arion: A Journal of Humanities and the Classics. 1990. 1(1). P. 61-105. Available from: www.jstor.org/stable/20163446_(Accessed on 17.01.2020)

10. Tokarev D. The descriptive and narrative aspects of ekphrasis ("The Dead Christ" by Holbein - Dostoevsky and the "Sistine Madonna" by Raphael - Zhukovsky//"Inexpressibly expressible": ekphrasis and problems of visual representation in a literary text: Collection of articles/Compilation and scientific editig D.V. Tokarev. Moscow: New literary review, 2013. P. 61-109. (in Russian: Токарев Д. Дескриптивный и нарративный аспекты экфрасиса («Мёртвый Христос» Гольбейна - Достоевского и «Сикстинская мадонна» Рафаэля = Жуковского//«Невыразимо выразимое»: экфрасис и проблемы репрезентации визуального в художественном тексте: Сборник статей/Составление и научная редакция Д. В. Токарева. Москва: Новое литературное обозрение, 2013. С. 61-109).

11. Turner M. The Literary Mind. The Origins of Thought and Language. New York, Oxford: Oxford University Press, 1996. 187 p.

12. Vorobyova O. P. Multimodality of the Real and Virtual in Virginia Woolf's "A Simple Melody": Cognitive and Affective Implications.//Proceedings of the International scientific conference of KNLU [Language - Literature - Arts: Cognitive-semiotic interface] (September 25-27, 2014)/Ed by O. P. Vorobyova. Kyiv: KNLU Publishing center, 2014. P. 17 (the title of the Proceedings is in Ukrainian: Матеріали Міжнародної наукової конференції КНЛУ [Мова - Література - Мистецтво: Когнітивно-семіотичний інтерфейс], (25-27 вересня 2014 р.)/відп. ред. О. П. Воробйова. Київ: Вид. центр КНЛУ, 2014.). 